\title{
Highly selective synthesis of D-amino acids via stereoinversion of corresponding counterpart by an in vivo cascade cell factory
}

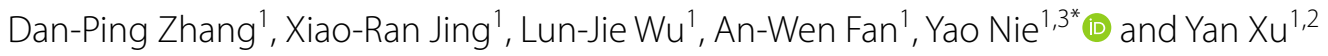

\begin{abstract}
Background: D-Amino acids are increasingly used as building blocks to produce pharmaceuticals and fine chemicals. However, establishing a universal biocatalyst for the general synthesis of D-amino acids from cheap and readily available precursors with few by-products is challenging. In this study, we developed an efficient in vivo biocatalysis system for the synthesis of D-amino acids from L-amino acids by the co-expression of membrane-associated L-amino acid deaminase obtained from Proteus mirabilis (LAAD), meso-diaminopimelate dehydrogenases obtained from Symbiobacterium thermophilum (DAPDH), and formate dehydrogenase obtained from Burkholderia stabilis (FDH), in recombinant Escherichia coli.

Results: To generate the in vivo cascade system, three strategies were evaluated to regulate enzyme expression levels, including single-plasmid co-expression, double-plasmid co-expression, and double-plasmid MBP-fused coexpression. The double-plasmid MBP-fused co-expression strain Escherichia coli pET-21 b-MBP-laad/pET-28a-dapdhfdh, exhibiting high catalytic efficiency, was selected. Under optimal conditions, $75 \mathrm{mg} / \mathrm{mL}$ of E. coli pET-21 b-MBPlaad/pET-28a-dapdh-fdh whole-cell biocatalyst asymmetrically catalyzed the stereoinversion of $150 \mathrm{mM}$ L-Phe to D-Phe, with quantitative yields of over $99 \%$ ee in 24 h, by the addition of $15 \mathrm{mM} \mathrm{NADP}^{+}$and $300 \mathrm{mM}$ ammonium formate. In addition, the whole-cell biocatalyst was used to successfully stereoinvert a variety of aromatic and aliphatic L-amino acids to their corresponding D-amino acids.
\end{abstract}

Conclusions: The newly constructed in vivo cascade biocatalysis system was effective for the highly selective synthesis of D-amino acids via stereoinversion.

Keywords: D-amino acids, In vivo, Cascade, Whole-cell biocatalysis, Stereoinversion, Selectivity

\section{Background}

D-Amino acids, as chiral auxiliaries and chiral synthons in organic synthesis, play important roles in the production of pharmaceuticals and fine chemicals [1-3]. For example, they are key components in $\beta$-lactam antibiotics, fertility drugs, anticoagulants, and pesticides $[1,4,5]$. Various methods have been developed for the synthesis

\footnotetext{
*Correspondence: ynie@jiangnan.edu.cn

${ }^{1}$ School of Biotechnology and Key laboratory of Industrial Biotechnology, Ministry of Education, Jiangnan University, 1800 Lihu Road, Wuxi 214122, China

Full list of author information is available at the end of the article
}

of D-amino acids. These methods can be categorized into two fundamentally different routes: chemical and biocatalytic approaches $[3,6,7]$. Chemical methods generally synthesize $\mathrm{D}$-amino acids by the chiral resolution of racemic D,L-amino acids or by asymmetric protocols from chiral or prochiral starting materials. However, high costs, low yields, low selectivity, and toxicity are major disadvantages of chemical methods due to $\mathrm{D}$-amino acid racemization $[6,8]$. There has been substantial progress in the development of biocatalytic methods in the past decade. Using enzymes as biocatalysts, D-amino acids can be produced under mild reaction conditions with 
high enantioselectivities, conversions, and space-time yields [9]. A number of enzymatic approaches have been used to produce $\mathrm{D}$-amino acids, including the synthesis of D-amino acids from D-hydantoin catalyzed by D-hydantoinase coupled with D-carbamoylase [10], asymmetric reductive amination of an $\alpha$-keto acid by $\mathrm{D}$-amino acid dehydrogenase or D-amino acid aminotransferase $[1,11]$, hydrolysis of an $\mathrm{N}$-acyl-D-amino acid by $\mathrm{N}$-acyl-D-amino acid amidohydrolase [12, 13], and the kinetic resolution of a racemic mixture by L-amino acid oxidase [7]. However, these methods usually require specific substrates that are generally expensive and not commercially available. Considering that $\mathrm{L}$-amino acids are mostly generated by fermentation from inexpensive and renewable natural sources, D-amino acid synthesis by stereoisomeric inversion with $\mathrm{L}$-amino acids as the starting substrate provides an economic and effective approach. However, there are only few reports about the applicability of this approach [3].

Multi-enzyme cascade reactions have recently become a very important synthetic strategy in the field of biocatalysis. They have various advantages, including the lack of a need for laborious intermediate recovery as well as the availability of cheap substrates [14-17]. Cascade catalysis could be performed in vivo or in vitro [14, 17-19]. In vivo cascade biocatalysis systems mainly involve the coexpression of multiple enzymes in a single host [20, 21]. The construction of an enzymatic cascade within a living host cell offers many advantages over in vitro methods, since whole cells can be used without further processing (e.g., protein purification) prior to the biotransformation, in vivo biocatalysis would be a more effective and easy-to-use strategy than the in vitro enzyme preparation $[14,22]$. In particular, when enzymes involved in the cascade route are membrane-associated and difficult to use freely in vitro, the in vivo cascade system is a good choice, and the cell-wall could protect the enzymes [23, 24]. As a powerful tool for the heterologous expression of various proteins, Escherichia coli is an ideal host for the development of whole-cell catalysts [17, 24, 25]. Multiple enzymes have been co-expressed in E. coli from one vector (polycistronic vector), from multiple vectors, or from a mixture [26]. A polycistronic vector generally consists of a cluster of genes under the control of a single strong promoter (e.g., T7 promoter), whereas each gene has its own ribosome-binding site (RBS) and a stop codon [21]. Owing to the advantages of the in vivo cascade biocatalysis system, the co-expression of multiple enzymes to set up an artificial reaction cascade in $E$. coli has become a powerful method to generate highly efficient designer cell catalysts [27]. Turner et al. co-expressed D-amino acid dehydrogenase (DAADH) from Corynebacterium glutamicum and glucose dehydrogenase (GDH) from
Bacillus megaterium, in E. coli, for the synthesis of $\mathrm{D}$-arylalanines from $\alpha$-keto acids (with $\alpha$-keto acid concentrations of $40 \mathrm{mM}$ ); D-arylalanines were produced in quantitative yields with $>98 \%$ ee [28]. Although these whole-cell reaction systems have been used to synthesize a variety of $\mathrm{D}$-amino acids, they require expensive and commercially unavailable substrates and show low catalytic efficiency. So far, there are few reports on the synthesis of $\mathrm{D}$-amino acids from $\mathrm{L}$-amino acids by in vivo cascade whole-cell catalysts.

We previously constructed a biocatalytic cascade system for the asymmetric synthesis of $\mathrm{D}$-amino acids by the stereoinversion of L-amino acids, using a combination of LAAD whole-cells (L-amino acid deaminase from Proteus mirabilis) (oxidative deamination module), DAPDH (H227V variant of meso-diaminopimelate dehydrogenases from Symbiobacterium thermophilum) (reductive amination module), and FDH (formate dehydrogenase from Burkholderia stabilis) (cofactor regeneration) [8, 29]. However, in this biocatalytic cascade system, the reaction intermediate needs to be transferred through the cell membrane for the connection between the two necessary steps of the stereoinversion reaction, which would affect the conversion efficiency of the entire biocatalytic system. In order to improve the catalytic efficiency of the cascade catalytic system, it would be necessary to develop an in vivo cascade cell factory for efficient asymmetric synthesis of $\mathrm{D}$-amino acids by the stereoinversion of $\mathrm{L}$-amino acids.

In this study, laad encoding the L-amino acid deaminase, dapdh encoding the meso-diaminopimelate dehydrogenase, and $f d h$ encoding formate dehydrogenase were co-expressed in $E$. coli for the asymmetric synthesis of $\mathrm{D}$-amino acids via the stereoinversion of $\mathrm{L}$-amino acids, as shown in Scheme 1. In the in vivo cascade catalytic system, LAAD catalyzing oxidative deamination and DAPDH catalyzing reductive amination were mainly used to catalyze the stereoinversion from L-amino acids to D-amino acids. By using only LAAD and DAPDH in the cells, it would be feasible to perform the stereoinversion transformation from $\mathrm{L}$-amino acids to $\mathrm{D}$-amino acids $[8,29]$. Because DAPDH is NADPH dependent, however, FDH was used to construct the NADPH recycling system, improving the cofactor regeneration and the conversion efficiency of the entire system. To regulate the expression levels of the enzymes responsible for each reaction module, different plasmid-based co-expression systems involving RBSs, promoters, and fusion tags were constructed. Then, induction was optimized to further increase the expression of the three enzymes. Finally, the effects of the biocatalytic conditions of recombinant $E$. coli whole-cell biocatalysts were investigated. By using the obtained in vivo cascade cell factory, L-Phe 


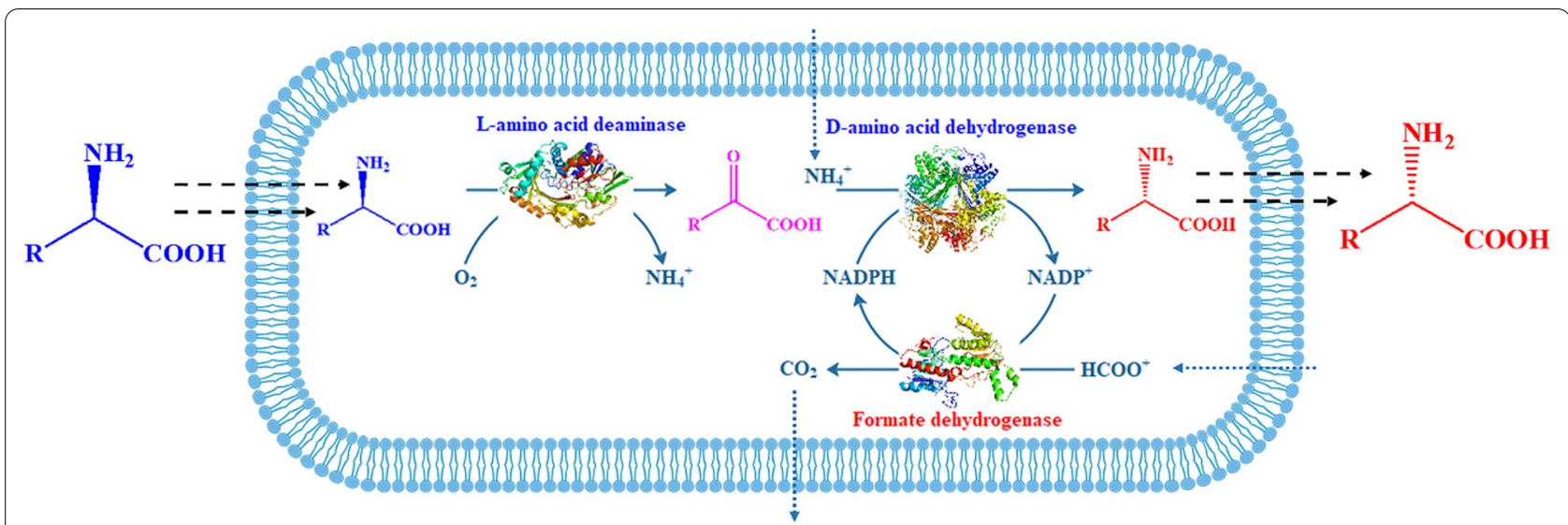

Scheme 1 Scheme for D-amino acid production from L-amino acids using an in vivo cascade biocatalysis system by co-expressing L-amino acid deaminase, D-amino acid dehydrogenase, and formate dehydrogenase

was stereoinverted to D-Phe with high conversion efficiency and optical purity. Moreover, recombinant E. coli whole-cell biocatalysts also transformed a variety of aromatic and aliphatic L-amino acids into the corresponding D-amino acids.

\section{Results and discussion}

\section{Construction of a multi-enzymatic cascade system}

The co-expression of multiple enzymes in a single host by a shared protein synthesis machinery could decrease enzyme production costs compared to those for individual enzyme expression in multiple hosts followed by enzyme cocktailing [21]. However, the co-expression of multiple proteins may lead to a metabolic burden during cell growth, which can result in poor overexpression and thus impaired catalytic performance [21, 22, 30]. The implementation of an in vivo multi-enzyme cascade system in a designer cell catalyst requires the fine tuning of expression levels. The precise co-expression strategy affects the expression of target enzymes and the catalytic efficiency of the co-expression system [17, 21, 31]. As shown in Scheme 1, in our study, the designed in vivo cascade route was mainly composed of two modules: an oxidative deamination module catalyzed by L-amino acid deaminase and a reductive amination module catalyzed by $\mathrm{D}$-amino acid dehydrogenase and formate dehydrogenase. To improve the overall catalytic efficiency of the co-expression system, three strategies were used to regulate the expression levels of the enzymes. (1) The three enzyme genes laad, dapdh, and $f d h$, which make up the oxidative deamination module (LAAD) and reductive amination modules (DAPDH and FDH), were cloned in a single pET-28a plasmid. Considering that the activity of LAAD was higher than that of DAPDH; accordingly, to enhance the expression of the DAPDH and FDH, the corresponding RBS sequences were added to dapdh and $f d h$ [8]. To regulate and balance the expression intensity of the three enzyme genes, the positions of the two modules on the plasmid were adjusted. (2) The oxidative deamination module and reductive amination module were constructed on two different plasmids, pET-21b and pET-28a, respectively (pET-21b and pET-28a both contained the T7 promoter with ampicillin and kanamycin genes, respectively). In this way, the expression of the genes of the two modules would be regulated by the T7 promoter on the two plasmids for the independent expression of the two modules, thereby minimizing interactions among the three genes. (3) Since LAAD was a membrane-binding protein, an MBP-tag was added to the double-plasmid system for the improvement of soluble expression of LAAD. According to this expression strategy, four co-expression strains named E. coli pET28a-laad-dapdh-fdh, E. coli pET-28a-dapdh-fdh-laad, E. coli pET-21b-laad/pET-28a-dapdh-fdh, and E. coli pET21b-MBP-laad/pET-28a-dapdh-fdh were constructed.

As shown in Fig. 1a, when the laad, dapdh, and fdh genes were cloned in the pET-28a plasmid, the position of laad had a great influence on the whole-cell catalyst. When laad was near the first position of the T7 promoter, although the expression of LAAD was very high, it mostly expressed as inclusion bodies, and DAPDH and FDH showed a certain degree of insoluble expression (Fig. 1b). Additionally, the catalytic activity of the E. coli pET-28a-laad-dapdh-fdh whole-cell biocatalyst was low (catalyzing $30 \mathrm{mM} \mathrm{L}-\mathrm{Phe}$ ), with only $1.5 \mathrm{mM}$ concentration of the product, D-Phe. There is evidence that the closer a gene is to the end of a polycistronic operon, the lower is its expression [31]. Consequently, the first and the last positions in the polycistron would have the greatest impact on gene expression. Considering that LAAD is 


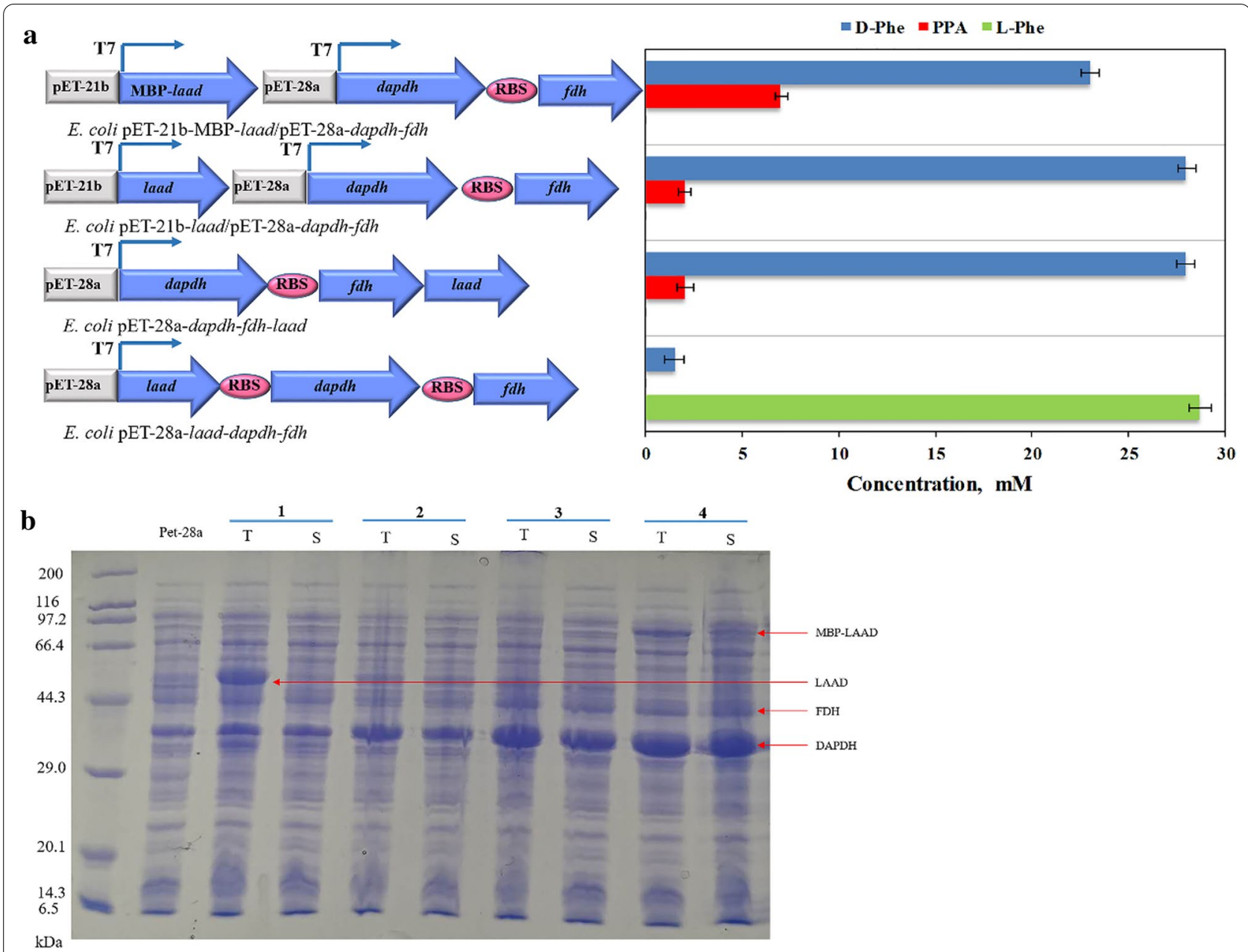

Fig. 1 Construction of a multi-enzymatic cascade system by the regulation of enzyme expression. a Gene expression optimization with plasmids for the biotransformation of L-Phe into D-Phe. Reactions were carried out in Tris-HCl buffer ( $50 \mathrm{mM}, \mathrm{pH}$ 9.0) at $30^{\circ} \mathrm{C}$. The reaction mixture contained $50 \mathrm{mg} / \mathrm{mL}$ whole-cell biocatalyst, $\mathrm{NADP}^{+}(3 \mathrm{mM}), \mathrm{NH}_{4} \mathrm{Cl}(90 \mathrm{mM})$, sodium formate $(60 \mathrm{mM})$, and L-Phe $(30 \mathrm{mM})$. All reactions were carried out in Tris- $\mathrm{HCl}$ buffer $(50 \mathrm{mM}, \mathrm{pH} 9.0)$ at $30^{\circ} \mathrm{C}$ and $220 \mathrm{rpm}$. The values were averaged from triplicate measurements. $\mathbf{b}$ SDS-PAGE of recombinant E. coli pET-28a-laad-dapdh-fdh (1), E. coli pET28a-dapdh-fdh-laad (2), E. coli pET21b-laad/pET-28a-dapdh-fdh (3), and E. coli pET-21b-MBP-laad/ pET-28a-dapdh-fdh (4). T: total cell lysate; S: soluble fraction. The samples were generated from $50 \mathrm{mg} / \mathrm{mL}$. coli

a membrane-binding protein, it may affect the expression of DAPDH and FDH when it is located near the first position of the T7 promoter. Therefore, in our study, the laad gene was placed at the end away from the $\mathrm{T} 7$ promoter. Surprisingly, all three enzymes exhibited normal expression, and the E. coli pET-28a-dapdh-fdh-laad whole-cell biocatalyst had high catalytic activity. The concentration of D-Phe in the reaction system was $28 \mathrm{mM}$, as shown in Fig. 1a and b. Subsequently, laad, dapdh, and $f d h$ were constructed in two different plasmids, and the expression and catalytic efficiency of the three genes in the doubleplasmid co-expression system were explored. When the three genes were co-expressed in two plasmids (laad or MBP-laad in the pET-21b plasmid, dapdh and $f d h$ in the
pET-28a plasmid, simultaneously), the two strains, E. coli pET-21b-MBP-laad/pET-28a-stdapdh-fdh and E. coli pET-21b-laad/pET-28a-dapdh-fdh, both had high catalytic activity; the concentrations of $\mathrm{D}$-Phe in the reaction system were 23 and $28 \mathrm{mM}$. As shown in Fig. 1b, in addition, when the genes laad, dapdh, and $f d h$ were cloned in pET-28a with laad at the first position close to the T7 promoter, the expression of laad increased. When laad was far from the T7 promoter, the expression of dapdh and $f d h$ was enhanced while the expression of laad was weakened. In the double-plasmid co-expression system, the expression of $d a p d h$ and $f d h$ was regulated by pET28 a separately. The expression of $d a p d h$ and $f d h$ was enhanced while the expression of laad was weakened. 
Therefore, the expression of laad in pET-21b did not lead to the formation of an inclusion body as much as that in pET-28a when laad was placed at the first position. Consequently, we obtained three co-expression strains with high catalytic activity for subsequent analyses. The expression conditions and catalytic conditions of the strains were studied to further improve the catalytic efficiency, and thereby, obtain an optimized co-expression whole-cell biocatalyst.

\section{Effects of co-expression conditions on the catalytic efficiency}

The effects of different expression conditions on the catalytic efficiency of recombinant strains were explored. As mentioned above, the substrate concentration was 30 $\mathrm{mM}$, and the catalytic reactions were mainly conducted to measure the catalytic activities of the constructed whole-cell catalysts and to determine the feasibility of the in vivo cascade reaction. In order to further improve the catalytic efficiency, the optimization of the expression conditions of recombinant cells were conducted under a higher substrate concentration. Thus, the concentration of $\mathrm{L}$-Phe was selected as $50 \mathrm{mM}$ in the following studies.

To optimize the protein expression conditions, the effects of the IPTG concentration and induction temperature on the biocatalyst activity of $E$. coli $\mathrm{pET}-21 \mathrm{~b}-$ MBP-laad/pET-28a-dapdh-fdh, E. coli pET-21b-laad/ pET-28a-dapdh-fdh, and E. coli pET-28a-dapdh-fdh-laad were studied. As shown in Fig. 2a, when the concentration of IPTG was $0.75 \mathrm{mM}$, the catalytic activity of the $E$. coli pET-21b-MBP-laad/pET-28a-dapdh-fdh whole-cell biocatalyst was the highest. Furthermore, higher concentrations of IPTG ( 1 and $1.5 \mathrm{mM})$ inhibited the catalytic activity of recombinant $E$. coli pET-21b-MBP-laad/ pET-28a-dapdh-fdh. As determined by SDS-PAGE, all three proteins expressed inclusion bodies to some extent when the concentrations of IPTG were 1 and $1.5 \mathrm{mM}$ (Additional file 1: Fig. S1). Therefore, the optimal IPTG concentration for E. coli pET-21b-MBP-laad/pET-28adapdh-fdh was $0.75 \mathrm{mM}$. Moreover, as shown in Fig. $2 \mathrm{~b}$ and c, the optimal IPTG concentrations for E. coli pET21b-laad/pET-28a-dapdh-fdh and E. coli pET28a-dapdhfdh-laad were 1.5 and $0.75 \mathrm{mM}$, respectively. The effects
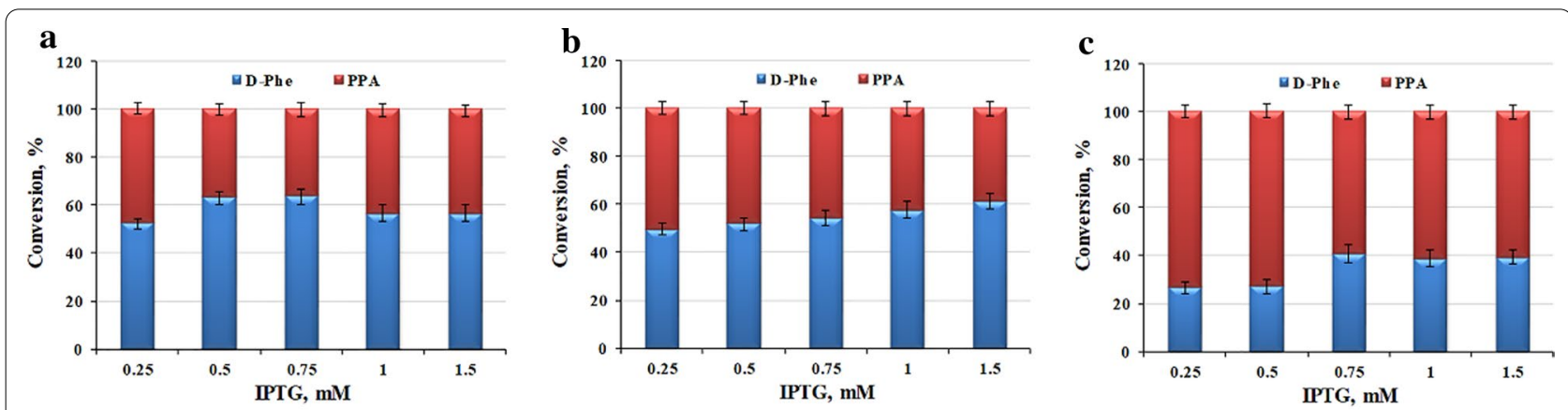

d
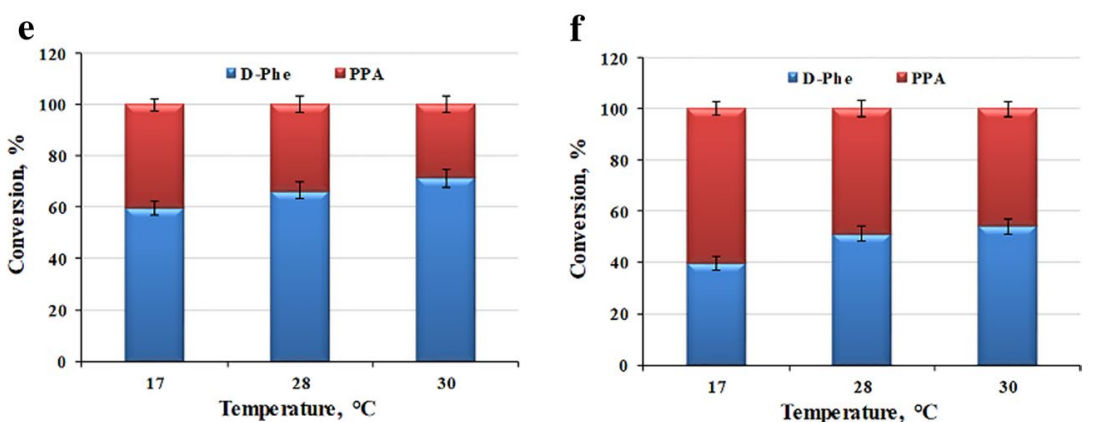

Fig. 2 Effect of expression conditions on the catalytic efficiency of E. coli pET-21b-MBP-laad/pET-28a-dapdh-fdh, E. coli

pET-21 b-laad/pET-28a-dapdh-fdh, and E. coli pET-28a-dapdh-fdh-laad. a Effect of the IPTG concentration on the catalytic activity of E. coli $\mathrm{pET}-21 \mathrm{~b}-\mathrm{MBP}-\mathrm{laad} / \mathrm{pET}-28 \mathrm{a}-\mathrm{dapdh}$-fdh. The induction temperature was $17^{\circ} \mathrm{C}$. $\mathbf{b}$ Effect of the IPTG concentration on the catalytic activity of E. coli pET-21b-laad/pET-28a-dapdh-fdh. The induction temperature was $17^{\circ} \mathrm{C}$. $\mathbf{~ E f f e c t ~ o f ~ t h e ~ I P T G ~ c o n c e n t r a t i o n ~ o n ~ t h e ~ c a t a l y t i c ~ a c t i v i t y ~ o f ~}$ E. coli pET-28a-dapdh-fdh-laad. The induction temperature was $17^{\circ} \mathrm{C}$. $\mathbf{d}$ Effect of the induction temperature on the catalytic activity of $E$. coli pET-21b-MBP-laad/pET-28a-dapdh-fdh. The IPTG concentration was $0.75 \mathrm{mM}$. e Effect of the induction temperature on the catalytic activity of $E$. coli pET-21b-laad/pET-28a-dapdh-fdh. The IPTG concentration was $1.5 \mathrm{mM}$. $\mathbf{f}$ Effect of the induction temperature on the catalytic activity of E. coli pET-28a-dapdh-fdh-laad. The IPTG concentration was $0.75 \mathrm{mM}$. The reaction mixture contained $50 \mathrm{mg} / \mathrm{mL}$ whole-cell biocatalyst, $\mathrm{NADP}^{+}(5 \mathrm{mM})$, $\mathrm{NH}_{4} \mathrm{Cl}(150 \mathrm{mM})$, sodium formate $(100 \mathrm{mM})$ and L-Phe $(50 \mathrm{mM})$. Reactions were all performed in Tris- $\mathrm{HCl}$ buffer $(50 \mathrm{mM}, \mathrm{pH} 9.0)$ at $30^{\circ} \mathrm{C}$ and $220 \mathrm{rpm}$ for $6 \mathrm{~h}$. The values were averaged from triplicate measurements 
of the IPTG concentration on the protein expression of $E$. coli pET-21b-laad/pET-28a-dapdh-fdh and E. coli pET28a-dapdh-fdh-laad are summarized Additional file 1: Fig. S2-S3.

The effect of induction temperature on catalytic activity was further investigated. As shown in Fig. $2 d-f$, for all three co-expressed strains, the catalytic activity of the whole-cell biocatalyst increased as the induction temperature increased. When the induction temperature was $30{ }^{\circ} \mathrm{C}$, the catalytic activity of the whole-cell biocatalyst was the highest. At the same time, under the optimal induction conditions, E. coli pET-21b-MBP-laad/pET28a-dapdh-fdh had the highest catalytic activity (the optimal IPTG concentration was $0.75 \mathrm{mM}$ and the optimal induction temperature was $30^{\circ} \mathrm{C}$ ). According to our previous research, the fusion of the MBP-tag not only improves the soluble expression of the membrane-bound LAAD, but also increases its catalytic performance [29]. Therefore, in the E. coli pET-21b-MBP-laad/pET-28adapdh-fdh co-expression system, the improvement of the catalytic activity of LAAD increased the catalytic activity of the E. coli pET-21b-MBP-laad/pET-28a-dapdh-fdh whole-cell catalyst. Although the activity of LAAD was higher than that of the DAPDH, its active expression level was low due to the membrane-bound property [8]. The catalytic efficiency of the oxidative deamination module would be lower than that of the reductive amination module which drives the reaction balance towards the accumulation of target product, and the oxidative deamination module would be the rate-limiting step. Therefore, the catalytic performance of the whole-cell catalyst was improved after construct optimization involving RBSs, promoters, gene positions, and fusion tags. Consequently, the recombinant E. coli pET-21b-MBP-laad/ pET-28a-dapdh-fdh was selected for further analyses.

\section{Effects of reaction components on catalytic efficiency}

To further improve the asymmetric production of $\mathrm{D}$-Phe by whole-cell biocatalysis, the reaction conditions were optimized systematically. In our previous work of constructing in vitro cascade catalytic reaction system, the LAAD whole-cell biocatalyst and the enzyme DAPDH were more active at $\mathrm{pH}$ 9.0, which was favorable for the oxidative deamination module and the reductive amination module [8]. Therefore, in this work, the reaction $\mathrm{pH}$ value was conducted according to the previously optimized catalytic conditions for the cascade reaction. Concerning the reaction components, the effects of the concentration of the E. coli pET-21b-MBP-laad/pET$28 \mathrm{a}-d a p d h-f d h$ whole-cell biocatalyst on conversion rates were firstly evaluated. The total conversion rate of D-Phe increased as the concentration of the whole-cell biocatalyst increased from 10 to $75 \mathrm{mg} / \mathrm{mL}$ wet cells
(Fig. 3a). Moreover, the highest conversion rate of 84.5 $\%$ was achieved using $75 \mathrm{mg} / \mathrm{mL}$ wet cells after $6 \mathrm{~h}$ of transformation. As no obvious increase in the conversion rate was observed from 100 to $125 \mathrm{mg} / \mathrm{mL}$ wet cells, higher concentration of whole-cell catalyst might lead to the decrease of mass transfer rate in the reaction system, thus reducing the catalytic efficiency of whole-cell catalyst. Then, $75 \mathrm{mg} / \mathrm{mL}$ wet cells were chosen as the optimal amount for whole-cell transformation, and was used for subsequent experiments.

$\mathrm{NH}_{4} \mathrm{Cl}$ and sodium formate were used as ammonia donors and co-substrates in the previously constructed in vitro catalytic system. Although the $\mathrm{NH}_{4}{ }^{+}$produced from LAAD could be recycled by DAPDH, the utilization rate of the generated $\mathrm{NH}_{4}{ }^{+}$was very low. To guarantee the reaction efficiency, it would be necessary to add exogenous ammonia donor into the in vivo cascade catalytic system. Accordingly, the effects of $\mathrm{NH}_{4} \mathrm{Cl}$ and sodium formate concentrations on the catalytic activity of in vivo cascade system were investigated. As shown in Fig. $3 \mathrm{~b}$ and c, the catalytic activity of the $E$. coli $\mathrm{pET}-21 \mathrm{~b}-$ MBP-laad/pET-28a-dapdh-fdh whole-cell biocatalyst increased as the ratio of $\mathrm{NH}_{4} \mathrm{Cl}$ and soddium formate to substrate increased. When the concentration of $\mathrm{NH}_{4} \mathrm{Cl}$ was 4 times the concentration of the substrate and the concentration of sodium formate was 3 times the concentration of the substrate, the catalytic activity of whole-cell biocatalyst was the highest. The conversion rate did not increase obviously with the increase of the ratio of $\mathrm{NH}_{4} \mathrm{Cl}$ and soddium formate. Therefore, the optimal ratio of $\mathrm{NH}_{4} \mathrm{Cl}$ to substrate was 4.0, and the optimum amount of sodium formate was 3 times the substrate concentration.

Finally, the effect of the $\mathrm{NADP}^{+}$concentration on the whole-cell biocatalyst efficiency was studied. As shown in Fig. 3d, 1-Phe was totally converted into phenylpyruvic acid (PPA) with the conversion reaching $100 \%$; while the conversion from PPA into D-Phe was varied with the change of the $\mathrm{NADP}^{+}$concentration. For the ratio of $\mathrm{NADP}^{+}$to substrate below 0.2 , the $\mathrm{NADP}^{+}$concentration had a slight effect on the whole-cell biocatalyst efficiency with the conversion over $80 \%$, and 0.1 -fold $\mathrm{NADP}^{+}$gave a high catalytic efficiency. However, for the ratio of $\mathrm{NADP}^{+}$to substrate over 0.2 , increasing the concentration of $\mathrm{NADP}^{+}$reduced the catalytic efficiency of the whole-cell biocatalyst, and the conversion was only $74 \%$ when 0.4 -fold $\mathrm{NADP}^{+}$were added into the reaction system. Accordingly, the optimal concentration of $\mathrm{NADP}^{+}$was 0.1 times the substrate concentration. During the reaction process, the cell membrane of the wholecell catalyst might be destroyed to a certain extent, which would increase the permeability of the cell membrane and utilization of the exogenous $\mathrm{NADP}^{+}$for cofactor regeneration in the cascade reaction [27, 32-34]. 

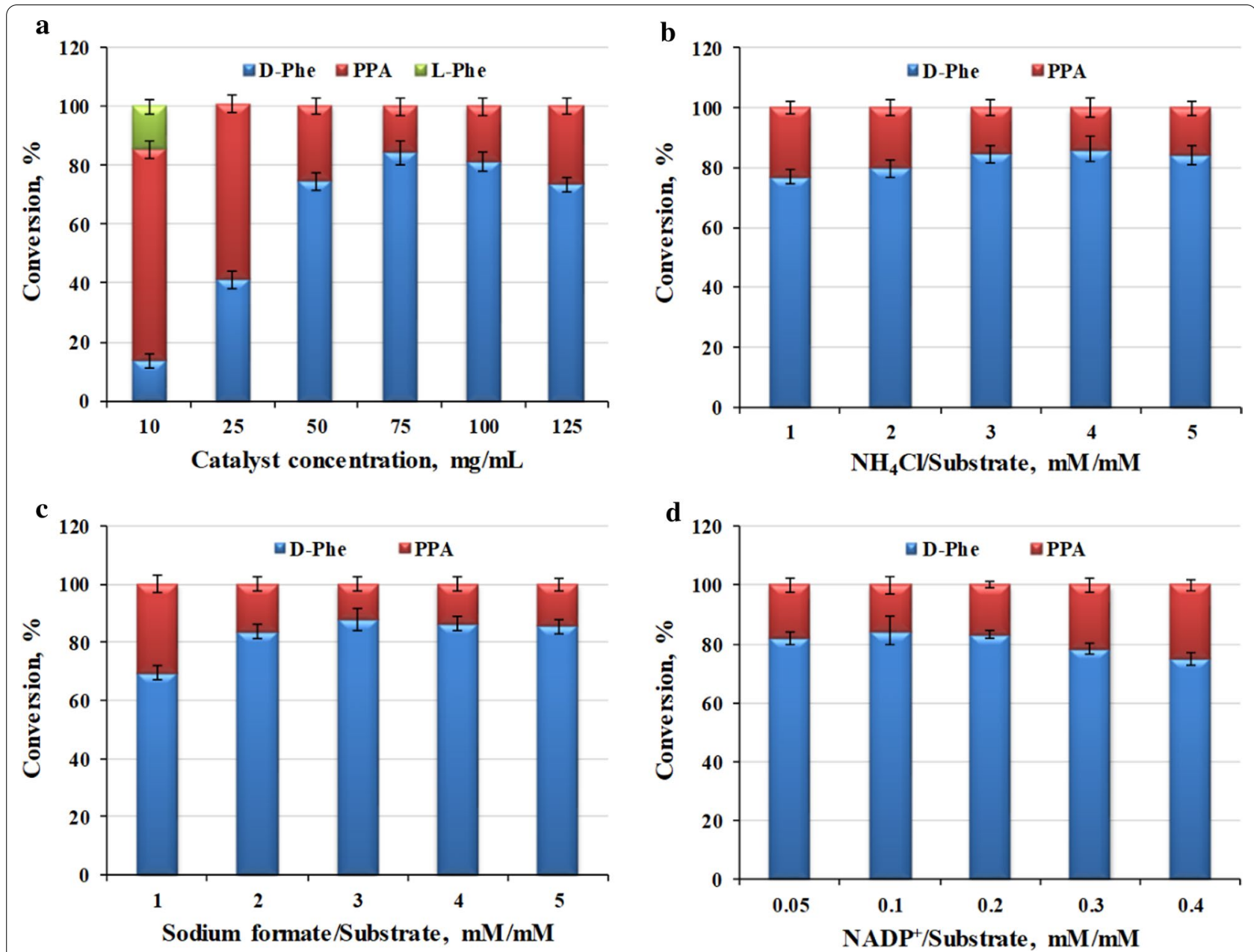

Fig. 3 Effects of different concentrations of whole-cell biocatalyst, $\mathrm{NH}_{4} \mathrm{Cl}$, sodium formate, and $\mathrm{NADP}^{+}$on catalytic efficiency. a Effect of the whole-cell biocatalyst concentration on whole-cell catalytic activity. The concentration of $\mathrm{NADP}^{+}$was $5 \mathrm{mM}$, the concentration of $\mathrm{NH}_{4} \mathrm{Cl}$ was $150 \mathrm{mM}$, and the concentration of sodium formate was $100 \mathrm{mM}$. $\mathbf{b}$ Effect of the $\mathrm{NH}_{4} \mathrm{Cl}$ concentration on whole-cell biocatalytic activity. The concentration of whole-cell biocatalyst was $75 \mathrm{mg} / \mathrm{mL}$ wet cells, the concentration of NADP ${ }^{+}$was $5 \mathrm{mM}$, and the concentration of sodium formate was $100 \mathrm{mM}$. c Effect of the sodium formate concentration on whole-cell biocatalytic activity. The concentration of whole-cell biocatalyst was 75 $\mathrm{mg} / \mathrm{mL}$ wet cells, the concentration of $\mathrm{NADP}^{+}$was $5 \mathrm{mM}$, and the concentration of $\mathrm{NH}_{4} \mathrm{Cl}$ was $200 \mathrm{mM}$. $\mathbf{d}$ Effect of the NADP ${ }^{+}$concentration on whole-cell biocatalytic activity. The concentration of whole-cell biocatalyst was $75 \mathrm{mg} / \mathrm{mL}$ wet cells, the concentration of NH${ }_{4} \mathrm{Cl}$ was $200 \mathrm{mM}$, and the concentration of sodium formate was $150 \mathrm{mM}$. All reactions were carried out in Tris- $\mathrm{HCl}$ buffer $\left(50 \mathrm{mM}, \mathrm{pH} \mathrm{9.0)}\right.$ at $30^{\circ} \mathrm{C}$ and $220 \mathrm{rpm}$ for $6 \mathrm{~h}$. The values were averaged from triplicate measurements

In the cascade catalytic route, $\mathrm{NH}_{4} \mathrm{Cl}$ and sodium formate are essential as an ammonia donor and cosubstrate [8]. Ammonium formate could play dual roles as both a co-substrate and $\mathrm{NH}_{4}{ }^{+}$donor for reductive amination. Therefore, ammonia formate was added to the reaction system to replace $\mathrm{NH}_{4} \mathrm{Cl}$ and sodium formate at a molar ratio of 1:1 to 5:1 (holding the concentration of substrate constant at $50 \mathrm{mM}$ ). As shown in Fig. 4, when the ratio of ammonium formate to substrate was $1: 1$, the conversion of D-Phe was $45 \%$. Whole-cell biocatalyst activity improved substantially in the presence of excess ammonium formate. The activity increased two-fold when the molar ratio was 2:1, probably because excess formate accelerated the reaction catalyzed by BsFDH and thus increased the efficiency of cofactor regeneration. Moreover, excess $\mathrm{NH}_{4}^{+}$could accelerate the reductive amination of PPA. However, no further increase in biocatalyst activity was detected when the molar ratio was further increased beyond 2:1. Consequently, the optimum molar ratio of ammonium formate to substrate for DPhe production was 2:1, and this ratio was used in further experiments. 


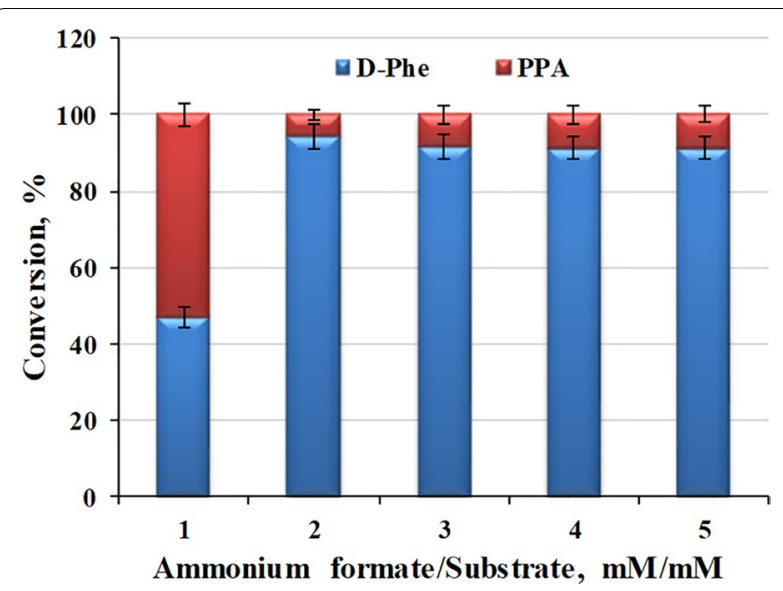

Fig. 4 Effect of the ammonium formate concentration on whole-cell biocatalytic activity. The concentration of E. coli PET-21b-MBP-laad/ pET-28a-dapdh-fdh wet cells was $75 \mathrm{mg} / \mathrm{mL}$, the concentration of $\mathrm{NADP}^{+}$was $5 \mathrm{mM}$, and the concentration of L-Phe was $50 \mathrm{mM}$. All reactions were carried out in Tris- $\mathrm{HCl}$ buffer $(50 \mathrm{mM}, \mathrm{pH} 9.0)$ at $30^{\circ} \mathrm{C}$ and $220 \mathrm{rpm}$ for $6 \mathrm{~h}$. The values were averaged from triplicate measurements

\section{Asymmetric synthesis of D-Phe from L-Phe}

Based on the results of single-factor optimization experiments, the asymmetric reduction of L-Phe at substrate concentrations of 50-150 mM by E. coli pET-21b-MBPlaad/pET-28a-dapdh-fdh was performed, and the time courses of bioconversion are illustrated in Fig. 5. Ammonia formate at twice the concentration of the substrate, was added to the reaction system as an ammonia donor and co-substrate. When the concentration of L-Phe was 50-100 $\mathrm{mM}$, the substrate was completely converted within $10 \mathrm{~h}$. In the early stage of the reaction, there was a certain degree of accumulation of the intermediate product PPA, but it was quickly converted into the final product. However, further increasing the L-Phe concentration to $150 \mathrm{mM}$ completely transformed the substrate into D-Phe within $24 \mathrm{~h}$. There was almost no accumulation of the intermediate product, PPA, in the reaction process. This may be explained by the high concentration of the substrate, L-Phe, which can inhibit the catalytic efficiency of LAAD to a certain extent, thereby reducing the
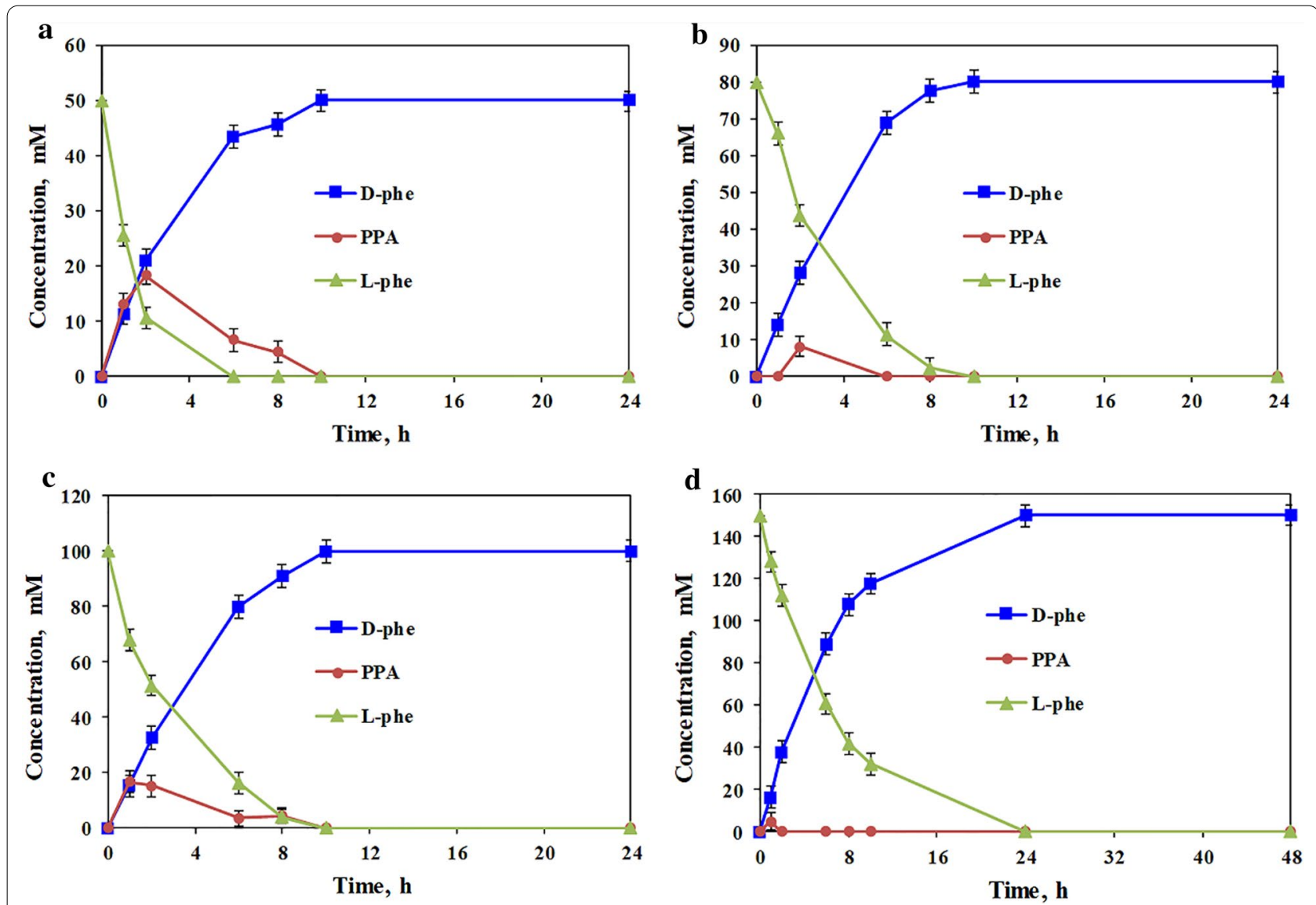

Fig. 5 Time course of D-Phe production for various concentrations of L-Phe, including a $50 \mathrm{mM}, \mathbf{b} 80 \mathrm{mM}, \mathbf{c} 100 \mathrm{mM}$, and d $150 \mathrm{mM}$. The concentration of E. coli pET-21b-MBP-laad/pET-28a-dapdh-fdh wet cells was $75 \mathrm{mg} / \mathrm{mL}$, the dosage of NADP+ was 0.1 times the substrate concentration, and the dosage of ammonium formate was twice the substrate concentration. All reactions were carried out in Tris- $\mathrm{HCl}$ buffer (50 $\mathrm{mM}, \mathrm{pH} 9.0)$ at $30{ }^{\circ} \mathrm{C}$ and $220 \mathrm{rpm}$. The values were averaged from triplicate measurements 
output of intermediate products, with rapid conversion by DAPDH. When $\mathrm{NH}_{4} \mathrm{Cl}$ and sodium formate were used as an ammonia donor and co-substrate, respectively, $E$. coli pET-21b-MBP-laad/pET-28a-dapdh-fdh catalyzed 100 and $150 \mathrm{mM}$ L-Phe, with conversion rates of $82.3 \%$ and $59.5 \%$ after $48 \mathrm{~h}$, respectively (Additional file 1: Fig. S4A and B). This is consistent with previous results for the in vitro cascade system with $\mathrm{NH}_{4} \mathrm{Cl}$ and sodium formate as the ammonia donor and co-substrate [8]. Therefore, the addition of ammonia formate could improve the catalytic efficiency of the E. coli pET-21b-MBP-laad/ pET-28a-dapdh-fdh whole cell biocatalyst. By using the obtained in vivo cascade cell factory $E$. coli pET-21bMBP-laad/pET-28a-dapdh-fdh, consequently, $150 \mathrm{mM}$ L-Phe was stereoinverted to D-Phe with high conversion efficiency and optical purity (conversion rate, 100\%; ee $>99 \%$ ), giving nearly 1.9 times increase of the substrate concentration compared with the previous in vitro cascade system. Therefore, this in vivo cascade catalytic system constructed in this work performed a high catalytic efficiency for the stereoinversion of L-amino acids under an increased substrate concentration. In addition, the ammonia formate concentration only needed to be twice the substrate concentration, improving the catalytic efficiency while reducing costs, thereby conforming to the view of green chemistry.

\section{Asymmetric synthesis of D-amino acids from corresponding counterparts}

The applicability of the E. coli pET-21b-MBP-laad/ pET-28a-dapdh-fdh whole-cell biocatalyst for the asymmetric conversion of a variety of natural and noncanonical L-amino acids into the corresponding D-amino acids was evaluated. As shown in Table 1, the L-amino acids $(30 \mathrm{mM})$ were mostly converted into the desired D-amino acids. For substrates with bulky groups, such as L-Phe, L-homophenylalanine, 2-chloro-L-phenylalanine, 3-chloro-L-phenylalanine and 4-chloro-L-phenylalanine, which are aromatic amino acids, the E. coli pET-21bMBP-laad/pET-28a-dapdh-fdh whole-cell biocatalyst produced the corresponding $\mathrm{D}$-amino acids with a high conversion rate $(100 \%)$ and optical purity $(>99 \% e e)$. In addition, the whole-cell biocatalyst could efficiently convert aliphatic amino acids, such as L-leucine, L-norvaline, L-glutamic acid, and L-methionine, to the corresponding $\mathrm{D}$-amino acids, with $\mathrm{D}$-leucine, D-glutamic acid, D-methionine and D-norvaline obtained in quantitative conversion and $>99 \% e e$. In particular, when the substrates were L-glutamic acid and L-methionine, the conversion rates were $100 \%$ and the optical purities were $>99 \% e e$. It also could be observed that the in vivo cascade catalytic system catalyzed limited aliphatic L-amino acid in a high conversion efficiency, which might be due
Table 1 Stereoinversion rates of various L-amino acids using E. coli pET-21b-MBP-laad/pET-28a-dapdh-fdh

\begin{tabular}{|c|c|c|}
\hline \multirow[t]{2}{*}{ Substrate } & \multicolumn{2}{|c|}{$\begin{array}{l}\text { E. coli pET-21b-MBP-laad/pET-28a- } \\
\text { dapdh-fdh whole-cell biocatalyst }\end{array}$} \\
\hline & Conversion (\%) & $\begin{array}{l}\text { Optical } \\
\text { purity (\% } \\
\text { ee) }\end{array}$ \\
\hline L-Leucine & 73.3 & $>99$ \\
\hline L-Glutamic acid & 100 & $>99$ \\
\hline L-Lysine & 51.5 & \\
\hline L-Methionine & 100 & $>99$ \\
\hline L-Norvaline & 61.8 & $>99$ \\
\hline L-Tyrosine & 45.3 & $>99$ \\
\hline L-Phenylalanine & 100 & $>99$ \\
\hline L-Tryptophan & 44.6 & \\
\hline L-Homophenylalanine & 100 & $>99$ \\
\hline 2-Chloro-L-phenylalanine & 100 & $>99$ \\
\hline 3-Chloro-L-phenylalanine & 100 & $>99$ \\
\hline 4-Chloro-L-phenylalanine & 100 & $>99$ \\
\hline 4-Methyl-L-phenylalanine & 67.4 & \\
\hline
\end{tabular}

Reaction conditions: $30 \mathrm{mM}$ substrate, $3 \mathrm{mM} \mathrm{NADP}^{+}, 60 \mathrm{mM}$ ammonium formate were added to $50 \mathrm{mM}$ Tris- $\mathrm{HCl}$ buffer ( $\mathrm{pH}$ 9.0). The concentration of E. coli pET-21b-MBP-laad/pET-28a-dapdh-fdh was $75 \mathrm{mg} / \mathrm{mL}$ wet cells. The reactions were carried out at $30^{\circ} \mathrm{C}$ and $220 \mathrm{rpm}$ for $24 \mathrm{~h}$.

a Optical purity (\%ee) was determined by HPLC after FDAA derivatization.

to somewhat low activity of LAAD and DAPDH towards certain kinds of substrates. These results were consistent with those for the in vitro cascade catalytic system in our previous study [8]. Consequently, the E. coli pET-21b-MBP-laad/pET-28a-dapdh-fdh whole-cell biocatalyst could catalyze a variety of natural and noncanonical L-amino acids with high substrate concentration and high efficiency. Therefore, the in vivo multi-enzyme cascade system is efficient and applicable for the asymmetric synthesis of D-amino acids via stereoinversion.

\section{Conclusions}

In this study, LAAD, DAPDH, and FDH were assembled in a multi-enzyme cascade system in vivo. The double-plasmid co-expression strain, named E. coli pET21b-MBP-laad/pET-28a-dapdh-fdh, was selected for further analyses owing to its high catalytic efficiency. After optimizing the reaction conditions for E. coli pET21b-MBP-laad/pET-28a-dapdh-fdh, $150 \mathrm{mM}$ L-Phe was quantitatively converted into D-Phe with greater than $99 \%$ ee in $24 \mathrm{~h}$ by the addition of a 0.1 -fold substrate concentration of $\mathrm{NADP}^{+}$and two-fold substrate concentration of ammonium formate. In particular, $E$. coli pET-21b-MBP-laad/pET-28a-dapdh-fdh efficiently converted a variety of readily available and inexpensive aromatic and aliphatic L-amino acids into the corresponding D-amino acids. This newly constructed in vivo 
multi-enzyme cascade system is a promising, sustainable, and cost-efficient approach for the synthesis of a broad range of $\mathrm{D}$-amino acids.

\section{Methods}

\section{Materials}

The laad gene from P. mirabilis (GenBank accession no. EU669819.1), the dapdh gene from $S$. thermophilum (GenBank accession no. BAD40410.1), and fdh from B. stabilis (GenBank accession no. ACF35003.1) were stored in our laboratory [8, 29, 35-38]. Enzymes, vectors, oligonucleotides, and other reagents for DNA cloning and amplification were obtained from Takara-Bio Co. (Kusatsu, Japan) and Novagen Co. (Madison, WI, USA). The L-amino acids and D-amino acids were purchased from Sinopharm Chemical Reagent Co., Ltd. (Shanghai, China). NADP ${ }^{+}$was purchased from Sigma-Aldrich (St. Louis, MO, USA). Acetonitrile and methanol for highperformance liquid chromatography (HPLC) were of chromatographic grade (Honeywell Co., Charlotte, NC, USA). All other chemicals were of analytical grade and commercially available.

\section{Construction of the multi-enzymatic cascade system}

Primers used in this study were listed in Additional file 1 : Table S1. To construct E. coli pET-28a-laad-dapdh-fdh, the laad gene, dapdh gene, and $f d h$ gene were cloned in pET-28a by homologous recombination. The RBSs for dapdh and $f d h$ were calculated using the Salis Lab RBS Calculator and the translation initiation rates were set to 100\% (https://salislab.net/software/doLogin). Then, the plasmid pET-28a-laad-dapdh-fdh was transformed into E. coli BL21 (DE3) cells. After plating, individual colonies were picked and the plasmids were sequenced. To construct E. coli pET-28a-dapdh-fdh-laad, the dapdh gene, $f d h$ gene, and laad gene were cloned into pET-28a by homologous recombination. Then, the plasmid pET-28adapdh-fdh-laad was transformed into E. coli BL21 (DE3) cells. After plating, individual colonies were picked and the plasmids were sequenced. To construct $E$. coli pET21b-laad/pET-28a-dapdh-fdh, the laad gene was cloned into the plasmid pET-21b, and the dapdh gene and $f d h$ gene were cloned into the plasmid pET-28a. Then, both pET-21b-laad and pET-28a-dapdh-fdh were transformed into E. coli BL21 (DE3) cells. Although both pET-28a and pET-21b employ pBR322 as origin, they contain kanamycin and ampicillin resistance genes, respectively. Under the selection pressure, the two plasmids can coexist stably in the same host cell [39]. After plating, individual colonies were picked and the plasmids were sequenced. To construct E. coli pET-21b-MBP-laad/pET-28adapdh-fdh, the laad gene was cloned in the plasmid pET21b-MBP, and the dapdh gene and $f d h$ gene were cloned in the plasmid pET-28a. Then, both pET-21b-MBP-laad and plasmid pET-28a-dapdh-fdh were transformed into E. coli BL21 (DE3) cells. After plating, individual colonies were picked and the plasmids were sequenced.

To investigate expression levels and catalytic efficiency, strains were propagated in $1 \mathrm{~L}$ of Luria-Bertani medium containing $100 \mathrm{mg} / \mathrm{mL}$ kanamycin (or both $100 \mathrm{mg} / \mathrm{mL}$ kanamycin and $100 \mathrm{mg} / \mathrm{mL}$ ampicillin) at $37{ }^{\circ} \mathrm{C}$. The culture was induced by the addition of isopropyl $\beta$-D-1thiogalactopyranoside (IPTG) to a final concentration of $0.5 \mathrm{mM}$ when the optical density $(\lambda=600 \mathrm{~nm})$ was 0.6-0.8, after which it was incubated for an additional $16 \mathrm{~h}$ at $17^{\circ} \mathrm{C}$ at $200 \mathrm{rpm}$. After centrifugation at $6000 \times g$ and $4{ }^{\circ} \mathrm{C}$ for $20 \mathrm{~min}$, the recombinant cells were washed with potassium phosphate buffer. To test the catalytic activity of co-expression recombinant cells, $50 \mathrm{mg} / \mathrm{mL}$ whole-cell biocatalyst, $3 \mathrm{mM} \mathrm{NADP}{ }^{+}, 90 \mathrm{mM} \mathrm{NH}_{4} \mathrm{Cl}, 60$ $\mathrm{mM}$ sodium formate, and $30 \mathrm{mM} \mathrm{L}$-Phe were added to 2 $\mathrm{mL}$ of Tris- $\mathrm{HCl}$ buffer $(50 \mathrm{mM}, \mathrm{pH}$ 9.0). After reaction at $30{ }^{\circ} \mathrm{C}$ and $220 \mathrm{rpm}$ for $6 \mathrm{~h}$, an equal volume of $10 \%(\mathrm{w} / \mathrm{v})$ trichloroacetic acid solution was added to stop the reaction. The mixture was centrifuged at $12000 \times g$ for $5 \mathrm{~min}$. The amount of PPA generated in the reaction process was determined using ferric chloride solution $[8,29,40]$ and the amounts of L-Phe and D-Phe were determined by HPLC after derivation with 1-fluor-2,4-dinitrophenyl-5-L-alanine amide (FDAA) [2, 8, 29].

\section{Effects of co-expression conditions on catalytic efficiency}

To investigate the effect of induction conditions on $E$. coli pET-21b-MBP-laad/pET-28a-dapdh-fdh, E. coli pET-21b-laad/pET-28a-dapdh-fdh, and E. coli pET28a-dapdh-bsfdh-laad whole cell biocatalytic activity, the three co-expression strains were propagated in $50 \mathrm{~mL}$ of Luria-Bertani medium containing $100 \mathrm{mg} /$ $\mathrm{mL}$ kanamycin (or $100 \mathrm{mg} / \mathrm{mL}$ kanamycin and $100 \mathrm{mg} /$ $\mathrm{mL}$ ampicillin) at $37{ }^{\circ} \mathrm{C}$. For investigating the effect of IPTG concentration on three co-expression strains, the culture was induced by the addition of IPTG to a final concentration of $0.25-1.5 \mathrm{mM}$ when the optical density $(\lambda=600 \mathrm{~nm})$ was $0.6-0.8$, after which it was incubated for an additional $16 \mathrm{~h}$ at $17{ }^{\circ} \mathrm{C}$ at $200 \mathrm{rpm}$. For investigating the effect of induction temperature on three coexpression strains, the concentration of IPTG used to induce the expression of E. coli $\mathrm{pET}$-21b-MBP-laad/pET28a-dapdh-fdh, E. coli pET-21b-laad/pET-28a-dapdhfdh, and E. coli pET-28a-dapdh-fdh-laad were $0.75,1.5$, and $0.75 \mathrm{mM}$, respectively. When the optical density $(\lambda=600 \mathrm{~nm})$ was $0.6-0.8$, after which it was incubated for an additional $16 \mathrm{~h}$ at $17^{\circ} \mathrm{C}, 28^{\circ} \mathrm{C}$, and $30{ }^{\circ} \mathrm{C}$ at 200 $\mathrm{rpm}$. After centrifugation at $6000 \times g$ and $4{ }^{\circ} \mathrm{C}$ for $20 \mathrm{~min}$, the recombinant cells were washed with potassium phosphate buffer. To test the catalytic activity of co-expression 
recombinant cells, $50 \mathrm{mg} / \mathrm{mL}$ whole-cell biocatalyst, 5 $\mathrm{mM} \mathrm{NADP}^{+}, 150 \mathrm{mM} \mathrm{NH}_{4} \mathrm{Cl}, 100 \mathrm{mM}$ sodium formate, and $50 \mathrm{mM} \mathrm{L}$-Phe were added to $2 \mathrm{~mL}$ of Tris- $\mathrm{HCl}$ buffer (50 mM, pH 9.0). After reaction at $30{ }^{\circ} \mathrm{C}$ and $220 \mathrm{rpm}$ for $6 \mathrm{~h}$, an equal volume of $10 \%(\mathrm{w} / \mathrm{v})$ trichloroacetic acid solution was added to stop the reaction. The mixture was centrifuged at $12000 \times g$ for $5 \mathrm{~min}$. The amount of PPA generated in the reaction process was determined using ferric chloride solution, and the amounts of L-Phe and D-Phe were determined by HPLC after derivation with FDAA.

\section{Effects of reaction components on catalytic efficiency}

E. coli pET-21b-MBP-laad/pET-28a-dapdh-fdh wholecell biocatalysts were propagated in $1 \mathrm{~L}$ of Luria-Bertani medium containing $100 \mathrm{mg} / \mathrm{mL}$ kanamycin and $100 \mathrm{mg} /$ $\mathrm{mL}$ ampicillin at $37^{\circ} \mathrm{C}$. The culture was induced by the addition of IPTG to a final concentration of $0.75 \mathrm{mM}$ when the optical density $(\lambda=600 \mathrm{~nm})$ was $0.6-0.8$, following by incubation for an additional $16 \mathrm{~h}$ at $30{ }^{\circ} \mathrm{C}$ at $200 \mathrm{rpm}$. After centrifugation at $6000 \times g$ and $4{ }^{\circ} \mathrm{C}$ for 20 $\mathrm{min}$, the recombinant cells were washed with potassium phosphate buffer. Then, the E. coli pET-21b-MBP-laad/ pET-28a-dapdh-fdh whole-cell biocatalysts were used to catalyze the conversion of $\mathrm{L}$-Phe to D-Phe. The reaction conditions were a whole-cell biocatalyst concentration of $10-125 \mathrm{mg} / \mathrm{mL}$ wet cells, $\mathrm{NH}_{4} \mathrm{Cl}$ concentration of 1-5 times the substrate concentration, sodium formate concentration of 1-5 times the substrate concentration, $\mathrm{NADP}^{+}$concentration of 0.05-0.4 times the substrate concentration, and L-Phe concentration of $50 \mathrm{mM}$. The reaction buffer was Tris- $\mathrm{HCl}$ buffer $(50 \mathrm{mM}, \mathrm{pH} 9.0)$. After reaction at $30^{\circ} \mathrm{C}$ and $220 \mathrm{rpm}$ for $6 \mathrm{~h}$, an equal volume of $10 \%(\mathrm{w} / \mathrm{v})$ trichloroacetic acid solution was added to stop the reaction. The mixture was centrifuged at $12000 \times \mathrm{g}$ for $5 \mathrm{~min}$. The amount of PPA generated in the reaction process was determined using ferric chloride solution, and the amounts of L-Phe and D-Phe were determined by HPLC after derivation with FDAA.

To investigate the effect of the ammonium formate concentration on E. coli pET-21b-MBP-laad/pET-28adapdh-fdh whole-cell catalytic activity, $75 \mathrm{mg} / \mathrm{mL} E$. coli pET-21b-MBP-laad/pET-28a-dapdh-fdh whole-cell biocatalyst, $5 \mathrm{mM} \mathrm{NADP}{ }^{+}$, ammonia formate concentration of 1-5 times the substrate concentration, and 50 $\mathrm{mM}$ L-Phe were added to $2 \mathrm{~mL}$ of Tris- $\mathrm{HCl}$ buffer ( 50 $\mathrm{mM}, \mathrm{pH} 9.0$ ) at $30^{\circ} \mathrm{C}$ and $220 \mathrm{rpm}$ for $6 \mathrm{~h}$. Then, an equal volume of $10 \%(\mathrm{w} / \mathrm{v})$ trichloroacetic acid solution was added to stop the reaction. The mixture was centrifuged at $12000 \times g$ for $5 \mathrm{~min}$. The amount of PPA generated in the reaction process was determined using ferric chloride solution, and the amounts of $\mathrm{L}-\mathrm{Phe}$ and $\mathrm{D}-\mathrm{Phe}$ were determined by HPLC after derivation with FDAA.

\section{Asymmetric synthesis of D-Phe from L-Phe}

The reaction mixture was composed of $50,80,100$, or $150 \mathrm{mM}$ L-Phe, $\mathrm{NADP}^{+}$at 0.1 times the substrate concentration, ammonia formate at 2 times the substrate concentration, and $75 \mathrm{mg} / \mathrm{mL}$ E. coli pET-21b-MBPlaad/pET-28a-dapdh-fdh whole-cell biocatalyst in $2 \mathrm{~mL}$ of Tris- $\mathrm{HCl}$ buffer (50 mM, pH 9.0). The reactions were carried out at $30^{\circ} \mathrm{C}$ and $220 \mathrm{rpm}$ and were terminated by the addition of an equal volume of $10 \%(\mathrm{w} / \mathrm{v})$ trichloroacetic acid solution. The amount of PPA generated in the reaction process was determined using ferric chloride solution, and the amounts of $\mathrm{L}$-Phe and $\mathrm{D}$-Phe were determined by HPLC, after derivation with FDAA.

\section{Asymmetric synthesis of $\mathrm{D}$-amino acids from corresponding counterparts}

Various L-amino acids, including L-leucine, L-glutamic acid, L-lysine, L-methionine, L-norvaline, L-tyrosine, L-Phe, L-tryptophan, L-homophenylalanine, 2-chloroL-phenylalanine, 3-chloro-L-phenylalanine, 4-chloroL-phenylalanine, and 4-methyl-L-phenylalanine, were used as substrates for the asymmetric synthesis of the corresponding D-amino acids using the E. coli $\mathrm{pET}-21 \mathrm{~b}-$ MBP-laad/pET-28a-dapdh-fdh whole-cell biocatalyst. The reaction mixture in $2 \mathrm{~mL}$ of Tris- $\mathrm{HCl}$ buffer $(50 \mathrm{mM}$, $\mathrm{pH}$ 9.0) contained $30 \mathrm{mM}$ substrate, $3 \mathrm{mM} \mathrm{NADP}{ }^{+}, 60$ $\mathrm{mM}$ ammonia formate, and $75 \mathrm{mg} / \mathrm{mL}$ whole-cell biocatalyst. The reactions were carried out at $30{ }^{\circ} \mathrm{C}$ and 220 $\mathrm{rpm}$ for $24 \mathrm{~h}$ and were terminated by the addition of an equal volume of $10 \%(\mathrm{w} / \mathrm{v})$ trichloroacetic acid solution. The concentrations of $\mathrm{L}$-amino acids and $\mathrm{D}$-amino acids were determined by HPLC following FDAA derivation.

\section{Analytical methods}

The amount of PPA in the reaction process was determined using ferric chloride solution $[8,41]$, which was prepared by dissolving $0.1 \mathrm{M}$ ferric chloride in $6 \mathrm{~mL}$ of dimethyl sulfoxide, followed by the addition of $4 \mathrm{~mL}$ of deionized water and $200 \mu \mathrm{L}$ of acetic acid, after which the solution was cooled in an ice bath. To determine the amount of PPA, a $15-\mu \mathrm{L}$ aliquot of the reaction sample was added to $1 \mathrm{~mL}$ of the ferric chloride solution, and the mixture was incubated at $25^{\circ} \mathrm{C}$ for $2 \mathrm{~min}$. The amount of PPA was immediately determined by measuring absorbance at $640 \mathrm{~nm}$ using a microplate reader.

The concentrations of L-amino acids and D-amino acids were determined by HPLC, following FDAA derivation. The FDAA reagent (Sigma-Aldrich) was used to produce diastereomeric derivatives of the amino acids. A $10 \mu \mathrm{L}$ sample of the amino acid, $8 \mu \mathrm{L}$ of $1 \mathrm{M} \mathrm{NaHCO}_{3}$, and $40 \mu \mathrm{L}$ of $1 \%(\mathrm{w} / \mathrm{v})$ FDAA in acetone were mixed and heated for $1 \mathrm{~h}$ at $40^{\circ} \mathrm{C}$. When the sample was cooled to room temperature, $8 \mu \mathrm{L}$ of $1 \mathrm{~N} \mathrm{HCl}$ and $934 \mu \mathrm{L}$ of $40 \%$ 
$(\mathrm{v} / \mathrm{v})$ aqueous acetonitrile were added to the mixture, followed by vortexing and filtering $(0.22 \mu \mathrm{m})$ for HPLC [2, 8]. Samples were analyzed using a Develosil ODS-UG-5 column $(150 \mathrm{~mm} \times 4.6 \mathrm{~mm})$. The HPLC conditions for analyzing phenylalanine were as follows: mobile phase A water $(0.05 \%$ trifluoroacetic acid), mobile phase B acetonitrile (0.05\% trifluoroacetic acid), with gradients from $20 \%$ B to $40 \%$ B over $40 \mathrm{~min}$, and from $40 \%$ B to $50 \%$ B over $5 \mathrm{~min}$ at a flow rate of $1 \mathrm{~mL} / \mathrm{min}$, detection at 340 $\mathrm{nm}, 40^{\circ} \mathrm{C}$, and an injection volume of $20 \mu \mathrm{L}$ (Additional file 1: Fig. S5). The HPLC conditions for analyzing other amino acids were as follows: mobile phase A $5 \%$ acetonitrile $(0.05 \%$ trifluoroacetic acid, $1 \%$ methanol), mobile phase B $60 \%$ acetonitrile $(0.05 \%$ trifluoroacetic acid, $1 \%$ methanol), linear gradient from $0 \%$ B to $100 \%$ B over 45 min at a flow rate $1 \mathrm{~mL} / \mathrm{min}$, injection volume of $20 \mu \mathrm{L}$ (Additional file 1: Fig. S6-17) [8, 42].

\section{Supplementary Information}

The online version contains supplementary material available at https://doi. org/10.1186/s12934-020-01506-X.

Additional file 1: Table S1. Primers used in this study. Fig. S1. SDSPAGE analysis of E. coli pET-21b-MBP-laad/pET-28a-dapdh-fdh induced by different concentrations of IPTG. T: total cell lysate; $S$ : soluble fraction. The samples were generated from $50 \mathrm{mg} / \mathrm{mL}$ of E. coli pET-21 b-MBP-laad/pET28a-dapdh-fdh cells. Fig. S2. SDS-PAGE analysis of E. coli pET-21b-laad/ pET-28a-dapdh-fdh induced by different concentrations of IPTG. T: total cell lysate; S: soluble fraction. The samples were generated from $50 \mathrm{mg} /$ $\mathrm{mL}$ of E. coli pET-21b-laad/pET-28a-dapdh-fdh cells. Fig. S3. SDS-PAGE analysis of E. coli pET-28a-dapdh-fdh-laad induced by different concentrations of IPTG. T: total cell lysate; S: soluble fraction. The samples were generated from $50 \mathrm{mg} / \mathrm{mL}$ of E. colii pET-28a-dapdh-fdh-laad cells. Fig. S4. Time course of $\mathrm{D}-$ Phe production from diferent concentration of $\mathrm{L}$-Phe. A: The concentration of L-Phe was 100 mM; B: The concentration of L-Phe was $150 \mathrm{mM}$. The concentration of E. coli pET-21 b-MBP-laad/pET-28adapdh-fdh whole-cell biocatalyst was $75 \mathrm{mg} / \mathrm{mL}$ wet cell, the dosage of $\mathrm{NADP}+$ was 0.1 time of substrate concentration, the dosage of $\mathrm{NH} 4 \mathrm{Cl}$ was 4 times of the substrate concentration, and the dosage of sodium formate was 3 times of substrate concentration. All the reactions were carried out in Tris- $\mathrm{HCl}$ buffer $(50 \mathrm{mM}, \mathrm{pH} 9.0)$ at $30{ }^{\circ} \mathrm{C}$ and $220 \mathrm{rpm}$. Fig. S5. HPLC analysis of L-Phe and D-Phe. Retention time of L-Phe is $34.620 \mathrm{~min}$; retention time of D-Phe is $41.287 \mathrm{~min}$. Fig. S6. HPLC analysis of L-leucine and D-leucine. Retention time of L-leucine is $32.313 \mathrm{~min}$; retention time of D-leucine is $36.100 \mathrm{~min}$. Fig. S7. HPLC analysis of L-glutamic acid and D-glutamic acid. Retention time of L-glutamic acid is $18.760 \mathrm{~min}$; retention time of D-glutamic acid is $20.327 \mathrm{~min}$. Fig. S8. HPLC analysis of L-lysine and D-lysine. Retention time of L-lysine is $28.267 \mathrm{~min}$; retention time of D-lysine is $34.46 \mathrm{~min}$. Fig. $\mathbf{S 9}$. HPLC analysis of L-methionine and D-methionine. Retention time of L-methionine is $28.54 \mathrm{~min}$; retention time of D-methionine is 31.92 min. Fig. S10. HPLC analysis of L-norvaline and D-norvaline. Retention time of $\mathrm{L}$-norvaline is $29.153 \mathrm{~min}$; retention time of D-norvaline is 33.120 min. Fig. S11. HPLC analysis of L-tyrosine and D-tyrosine. Retention time of L-tyrosine is $37.067 \mathrm{~min}$; retention time of D-tyrosine is $40.067 \mathrm{~min}$. Fig. S12. HPLC analysis of L-tryptophan and D-tryptophan. Retention time of L-tryptophan is $30.773 \mathrm{~min}$; retention time of L-tryptophan is 33.153 min. Fig. S13. HPLC analysis of L-homophenyalanine and D-homophenyalanine. Retention time of L-homophenyalanine is $35.04 \mathrm{~min}$; retention time of D-homophenyalanine is $38.713 \mathrm{~min}$. Fig. S14. HPLC analysis of 2-chloro-L-phenylalanine and 2-chloro-D-phenylalanine. Retention time of 2-chloro-L-phenylalanine is $37.66 \mathrm{~min}$; retention time of 2-chloro-D-phenylalanine is $34.227 \mathrm{~min}$. Fig. S15. HPLC analysis of 3-chloro-L-phenylalanine and 3-chloro-D-phenylalanine. Retention time of 3-chloro-L-phenylalanine is $35.473 \mathrm{~min}$; retention time of 3-chloro-D-phenylalanine is $38.713 \mathrm{~min}$. Fig. S16. HPLC analysis of 4-chloro-L-phenylalanine and 4-chloro-D-phenylalanine. Retention time of 4-chloro-L-phenylalanine is $36.12 \mathrm{~min}$; retention time of 4-chloro-D-phenylalanine is $39.42 \mathrm{~min}$. Fig. S17. HPLC analysis of 4-methyl-L-phenylalanine and 4-methyl-D-phenylalanine. Retention time of 4-methyl---phenylalanine is 35.347 min; retention time of 4-methylD-phenylalanine is $38.600 \mathrm{~min}$.

\section{Acknowledgements}

We would like to thank Editage (http://www.editage.cn) for English language editing.

\section{Authors' contributions}

DZ and YN designed the experiments. DZ led the performance of the experiments, analysis of the data and writing of the paper. XJ, LW, and AF participated in experiments and analysis. DZ, YN and YX participated in editing the paper. All authors read and approved the final manuscript.

\section{Funding}

This work was financially supported by the National Natural Science Foundation of China [Grant Numbers 21676120, 31872891], the Program of Introducing Talents of Discipline to Universities [Grant Number 111-2-06], the High-End Foreign Experts Recruitment Program [Grant Number G20190010083], the Program for Advanced Talents within Six Industries of Jiangsu Province [Grant Number 2015-NY-007], the National Program for Support of Top-notch Young Professionals, Postgraduate Research \& Practice Innovation Program of Jiangsu Province [Grant Number KYCX18_1794], the Fundamental Research Funds for the Central Universities [Grant Number JUSRP51504], the Project Funded by the Priority Academic Program Development of Jiangsu Higher Education Institutions, Top-notch Academic Programs Project of Jiangsu Higher Education Institutions, the Jiangsu province "Collaborative Innovation Center for Advanced Industrial Fermentation" industry development program, the Program for the Key Laboratory of Enzymes of Suqian (M201803), and the National First-Class Discipline Program of Light Industry Technology and Engineering [Grant Number LITE2018-09].

\section{Availability of data and materials}

We declared that materials described in the manuscript, including all relevant raw data, will be freely available to any scientist wishing to use them for noncommercial purposes, without breaching participant confidentiality.

\section{Ethics approval and consent to participate}

This article does not contain any studies with human participants or animals performed by any of the authors.

\section{Consent for publication}

Not applicable.

\section{Competing interests}

The authors declare that they have no competing interests.

\section{Author details}

${ }^{1}$ School of Biotechnology and Key laboratory of Industrial Biotechnology, Ministry of Education, Jiangnan University, 1800 Lihu Road, Wuxi 214122, China. ${ }^{2}$ State Key Laboratory of Food Science and Technology, Jiangnan University, Wuxi 214122, China. ${ }^{3}$ Suqian Industrial Technology Research Institute of Jiangnan University, Suqian 223814, China.

Received: 20 July 2020 Accepted: 29 December 2020

Published online: 09 January 2021

\section{References}

1. Vedha-Peters K, Gunawardana M, Rozzell JD, Novick SJ. Creation of a broad-range and highly stereoselective $\mathrm{D}$-amino acid dehydrogenase for the one-step synthesis of D-amino acids. J Am Chem Soc. 2006;128:10923-9. 
2. Hanson RL, Davis BL, Goldberg SL, Johnston RM, Parker WL, Tully TP, Montana MA, Patel RN. Enzymatic preparation of a D-amino acid from a racemic amino acid or keto acid. Org Process Res Dev. 2008;12:1119-29.

3. Pollegioni L, Rosini E, Molla G. Advances in enzymatic synthesis of D-amino acids. Int J Mol Sci. 2020;21:3206-22.

4. Merviel P, Najas S, Campy H, Floret S, Brasseur F. Use of GNRH antagonists in reproductive medicine. Minerva Ginecol. 2005;57:29-43.

5. Isobe K, Tamauchi H, Fuhshuku K, Nagasawa S, Asano Y. A simple enzymatic method for production of a wide variety of $\mathrm{D}$-amino acids using L-amino acid oxidase from Rhodococcus sp. AlU Z-35-1. Enzyme Res. 2010;2010:567210.

6. Xue YP, $\mathrm{Cao} \mathrm{CH}$, Zheng YG. Enzymatic asymmetric synthesis of chiral amino acids. Chem Soc Rev. 2018;47:1516-61.

7. Gao XZ, Ma QY, Zhu HL. Distribution, industrial applications, and enzymatic synthesis of D-amino acids. Appl Microbiol Biotechnol. 2015;99:3341-9.

8. Zhang DP, Jing XR, Zhang WL, Nie Y, Xu Y. Highly selective synthesis of D-amino acids from readily available L-amino acids by a one-pot biocatalytic stereoinversion cascade. RSC Adv. 2019;9:29927-35.

9. Almhjell PJ, Boville CE, Arnold FH. Engineering enzymes for noncanonical amino acid synthesis. Chem Soc Rev. 2018;47:8980-97.

10. Liu YF, Xu GC, Han RZ, Dong JJ, Ni Y. Identification of D-carbamoylase for biocatalytic cascade synthesis of D-tryptophan featuring high enantioselectivity. Bioresour Technol. 2018;249:720-8.

11. Park ES, Shin JS. Deracemization of amino acids by coupling transaminases of opposite stereoselectivity. Adv Synth Catal. 2015;356:3505-9.

12. Baxter S, Royer S, Grogan G, Brown F, Holt-Tiffin KE, Taylor IN, Fotheringham IG, Campopiano DJ. An improved racemase/acylase biotransformation for the preparation of enantiomerically pure amino acids. J Am Chem Soc. 2012;134:19310-3.

13. Morán-Ramallal R, Liz R, Gotor V. Regioselective and stereospecific synthesis of enantiopure 1,3-oxazolidin-2-ones by intramolecular ring opening of 2-(boc-aminomethyl)aziridines. Org Lett. 2008;10:1935-8.

14. France SP, Hepworth LJ, Turner NJ, Flitsch SL. Constructing biocatalytic cascades: in vitro and in vivo approaches to de novo multi-enzyme pathways. ACS Catal. 2017;7:710-24.

15. Xue YP, Wang C, Wang DC, Liu ZQ, Zheng YG. Highly efficient deracemization of racemic 2 -hydroxy acids in a three-enzyme co-expression system using a novel ketoacid reductase. Appl Biochem Biotechnol. 2018;186:563-75.

16. Santacoloma PA, Sin GR, Gernaey KV, Woodley JM. Multienzymecatalyzed processes: next-generation biocatalysis. Org Biomol Chem. 2011;15:203-12.

17. Hou Y, Gao B, Cui J, Tan Z, Qiao C, Jia S. Combination of multi-enzyme expression fine-tuning and co-substrates addition improves phenyllactic acid production with an Escherichia coli whole-cell biocatalyst. Bioresour Technol. 2019;287:121423-31.

18. Quin MB, Wallin KK, Zhang G, Schmidt-Dannert C. Spatial organization of multi-enzyme biocatalytic cascades. Org Biomol Chem. 2017;15:4260-71.

19. Zu H, Gu J, Zhang H, Fan AW, Nie Y, Xu Y. Highly enantioselective synthesis of (R)-1,3-butanediol via deracemization of the corresponding racemate by a whole-cell stereoinverting cascade system. Microb Cell Fact. 2020;19:125.

20. Ninh PH, Honda K, Sakai T, Okano K, Ohtake H. Assembly and multiple gene expression of thermophilic enzymes in Escherichia coli for in vitro metabolic engineering. Biotechnol Bioeng. 2015;112:189-96.

21. Chen H, Huang R, Zhang YP. Systematic comparison of co-expression of multiple recombinant thermophilic enzymes in Escherichia coli BL21(DE3). Appl Microbiol Biotechnol. 2017;101:4481-93.

22. Wachtmeister J, Rother $D$. Recent advances in whole cell biocatalysis techniques bridging from investigative to industrial scale. Curr Opin Biotechnol. 2016;42:169-77.

23. de Carvalho CC. Enzymatic and whole cell catalysis: finding new strategies for old processes. Biotechnol Adv. 2011;29:75-83.

24. de Carvalho CC. Whole cell biocatalysts: essential workers from nature to the industry. Microb Biotechnol. 2017;10:250-63.
25. Quehl P, Hollender J, Schuurmann J, Brossette T, Maas R, Jose J. Coexpression of active human cytochrome P450 1A2 and cytochrome P450 reductase on the cell surface of Escherichia coli. Microb Cell Fact. 2016;15:26.

26. Jiang W, Fang B. Construction of a tunable multi-enzyme-coordinate expression system for biosynthesis of chiral drug intermediates. Sci Rep. 2016;6:30462-8.

27. Gourinchas G, Busto E, Killinger M, Richter N, Wiltschi B, Kroutil W. A synthetic biology approach for the transformation of $D$-a-amino acids to the corresponding enantiopure (R)- or (S)-a-hydroxy acids. Chem Commun. 2015;51:2828-31.

28. Parmeggiani F, Ahmed ST, Thompson MP, Weise NJ, Galman JL, Gahloth D, Dunstan MS, Leys D, Turner NJ. Single-biocatalyst synthesis of enantiopure D-arylalanines exploiting an engineered $\mathrm{D}$-amino acid dehydrogenase. Adv Synth Catal. 2016;358:3298-306.

29. Zhang DP, Jing XR, Fan AW, Liu H, Nie Y, Xu Y. Active expression of membrane-bound L-amino acid deaminase from Proteus mirabilis in recombinant Escherichia coli by fusion with maltose-binding protein for enhanced catalytic performance. Catalysts. 2020;10:1-11.

30. Muller CA, Dennig A, Welters T, Winkler T, Ruff AJ, Hummel W, Groger $H_{\text {, }}$ Schwaneberg U. Whole-cell double oxidation of $n$-heptane. J Biotechnol. 2014;191:196-204.

31. Xiong TZ, Jia P, Jiang J, Bai YJ, Fan T-P, Zheng XH, Cai YJ. One-pot, threestep cascade synthesis of D-danshensu using engineered Escherichia coli whole cells. J Biotechnol. 2019;300:48-54.

32. Chen LF, Zhang YP, Fan HY, Wu K, Lin JP, Wang HL, Wei DZ. Efficient bioreductive production of (R)-N-Boc-3-hydroxypiperidine by a carbonyl reductase. Catal Commun. 2017;97:5-9.

33. Zheng GW, Liu YY, Chen Q, Huang L, Yu HL, Lou WY, Li CX, Bai YP, Li AT, $\mathrm{Xu} \mathrm{JH}$. Preparation of structurally diverse chiral alcohols by engineering ketoreductase CgKR1. ACS Catal. 2017:7:7174-81.

34. Chen X, Zhang H, Maria-Solano MA, Liu W, Li J, Feng J, Liu X, Osuna S, Guo R-T, Wu Q, Zhu D, Ma Y. Efficient reductive desymmetrization of bulky 1,3-cyclodiketones enabled by structure-guided directed evolution of a carbonyl reductase. Nat Catal. 2019:2:931-41.

35. Liu L, Hossain GS, Shin HD, Li JH, Du GC, Chen J. One-step production of a-ketoglutaric acid from glutamic acid with an engineered $\mathrm{L}$-amino acid deaminase from Proteus mirabilis. J Biotechnol. 2013;164:97-104.

36. Gao XZ, Chen X, Liu WD, Feng JH, Wu QQ, Hua L, Zhu DM. A novel mesodiaminopimelate dehydrogenase from Symbiobacterium thermophilum: overexpression, characterization, and potential for D-amino acid synthesis. Appl Environ Microbiol. 2012;78:8595-600.

37. Gao XZ, Huang F, Feng JH, Chen X, Zhang HL, Wang ZX, Wu QQ, Zhu DM. Engineering the meso-diaminopimelate dehydrogenase from Symbiobacterium thermophilum by site saturation mutagenesis for D-phenylalanine synthesis. Appl Environ Microbiol. 2013;79:5078-81.

38. Hatrongjit R, Packdibamrung K. A novel NADP+-dependent formate dehydrogenase from Burkholderia stabilis 15516: screening, purification and characterization. Enzyme Microb Technol. 2010;46:557-61.

39. Velappan N, Sblattero D, Chasteen L, Pavlik P, Bradbury AR. Plasmid incompatibility: more compatible than previously thought? Protein Eng Des Sel. 2007;20:309-13.

40. Hou Y, Hossain GS, Li J, Shin HD, Liu L, Du G. Production of phenylpyruvic acid from L-phenylalanine using an L-amino acid deaminase from Proteus mirabilis: comparison of enzymatic and whole-cell biotransformation approaches. Appl Microbiol Biotechnol. 2015;99:8391-402.

41. Molla G, Melis R, Pollegioni L. Breaking the mirror: L-amino acid deaminase, a novel stereoselective biocatalyst. Biotechnol Adv. 2017;35:657-68.

42. Bhushan R, Bruckner H. Marfey's reagent for chiral amino acid analysis: a review. Amino Acids. 2004;27:231-47.

\section{Publisher's Note}

Springer Nature remains neutral with regard to jurisdictional claims in published maps and institutional affiliations. 